\title{
金修飾光ファイバーセンサーシステムによるカルボン酸エステル 及びエステル系潤滑剤の分析
}

\author{
満 塩 勝 ${ }^{\mathbb{B} *}$, 吉留 俊史 ${ }^{* *}$, 鎌田 薩男 ${ }^{* *}$ \\ Analyses of carboxylic acid esters and lubricants using a gold-coated \\ optical-fiber sensor system \\ Masaru Mitsushio*, Toshifumi Yoshidome and Satsuo Kamata ${ }^{* *}$

\begin{abstract}
* Department of Applied Chemical Engineering, Graduate School of Engineering, Kagoshima University, 121 - 40, Korimoto, Kagoshima 890-0065

${ }^{* *}$ Department of Applied Chemistry and Chemical Enginnering, Faculty of Engineering, Kagoshima University, 1-21-40, Korimoto, Kagoshima 890-0065
\end{abstract}

(Received 7 January 2000, Accepted 29 February 2000)

\begin{abstract}
The concentrations of carboxylic acid esters and lubricants were measured by using a goldcoated optical-fiber sensor system. The sensor system consisted of a He-Ne laser, an optical fiber, and a detector. A part of the optical fiber, which was in contact with a sample solution, was coated by a gold thin film after removing the fiber clad. The intensity of the transmitted laser light by the fiber varied with the refractive index of the sample solution. The transmittance of the fiber on ethyl formate with a refractive index below 1.37 decreased with increasing the concentration of the formate, while that of the fiber on the other ester compounds with a refractive index, above 1.37 , such as diethyl sebacate and DOS, increased with increasing these material concentrations. The difference in the concentration dependence of the transmittance was thought to be explained on the basis of the refractive index of the sample solution. The sensitivity of this sensor system was good for these carboxylic acid esters and lubricants. In particular, plots of the transmittance against the concentrations of DOS and DOA were liner over the range of 20 to $80 \%$. Thus, this gold-coated optical fiber sensor system can be used to determine the concentration of carboxylic acid esters and lubricants.
\end{abstract}

Keywords : gold-coated optical-fiber; lubricant; DOS; DOA; carboxylic acid esters.

\section{1 緒言}

機械産業が発達している現代において，潤滑剤の持つ役 割は極めて大きい，特に，産業機械のほとんどは回転運動 を基本とした動作を行うため，機械の動作を円滑にするた めのベアリングには，高荷重，高回転に耐えうる潤滑剤が 必要とされる。

このような条件下で用いられる潤滑剤として，セバシン 酸ビス2-エチルヘキシル（DOS）や，アジピン酸ビス 2-

* 鹿垐島大学大学院理.丁学研究科: 890-0065 鹿児島県鹿览島 市郡元 1-21-40

** 鹿児島大学 T学部応用化学工学科: 890-0065 鹿児島県鹿児 島市郡元 1-21-40
エチルヘキシル（DOA）のようなジカルボン酸ジエステ ル系潤滑剂がある。これらは，耐寒性に優れている高性能 潤滑剂である”。これらの潤滑㝄の性能を分析・試験する 方法には様々な方法がある゙ー6が，潤滑剂の状態を連続的 にリアルタイムで観測できる方法はほとんどない．

近年，クラッドを除去した光ファイバーをセンサーとし て用いる方法が研究されている。これには，単色光の吸光

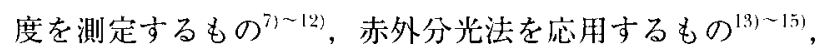

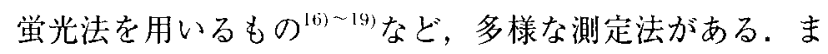
たこの方法を応用した光ファイバーセンサーシステムに よるアルコール類の濃度測定などがある゙”.

本報では，数種の脂肪酸エチルエステル及び合成潤滑剂 


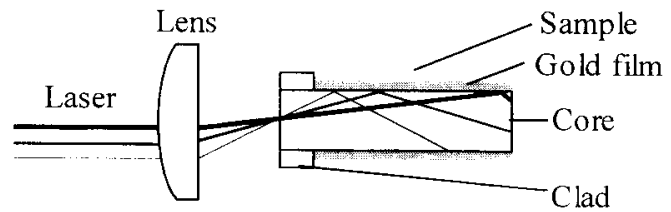

(a)

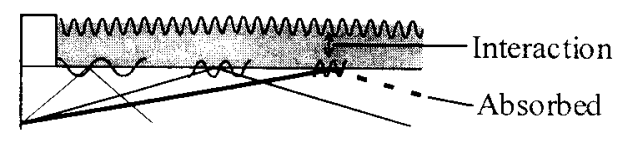

(b)

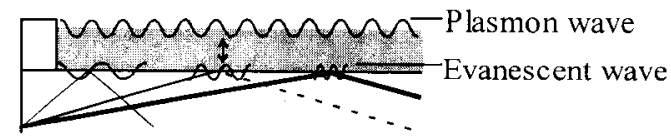

(c)

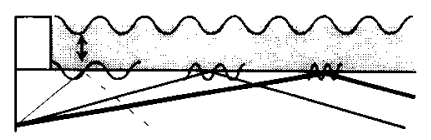

Fig. 1 Schematic drawings for light absorption of the gold-coated unclad optical fiber ${ }^{2(i)}$

の DOS 及び DOAについて, 金修飾光ファイバーセンサ ーシステムを用いる濃度測定を検討し，良好な結果を得た ので報告する.

$$
2 \text { 実験 }
$$

\section{$2 \cdot 1$ 試 料}

測定試料として用いた酶酸エチル,プロピオン酸エチル， マロン酸ジエチルは和光純薬製の市販特級品, キ酸エチル, セバシン酸ジエチルは和光純薬製の市販一級品, アジピン 酸ジエチルは関東化学製の市販特級品である。これらの試 薬は，市販品をそのまま使用した，また，DOS及び DOA は大八化学工業より提供されたものを用いた。その他, 溶 媒等に使用した試薬はすべて市販特級品である。

\section{$2 \cdot 2$ 測定原理}

実験装置には，既報『にに報告した金修飾光ファイバーシ ステムを用いた．Fig. 1 に原理図 ${ }^{201}$ を示す，光ファイバー 内で光が全反射を起こすと，その反射点に执いて入射角に よって波数が決まるエバネッセント波が発生する。レンズ によって光ファイバーに入射されるレーザー光 $(\mathrm{He}-\mathrm{Ne}$ レーザー，632.8 nm）は，様々な角度で入射されるため， 光ファイバー表面上には様々な波数のエバネッセント波が 発生する. 更に, レーザー光は光軸から離れるに従って光 の強度が急速に減少するため，入射角によって光の強さが 異なる。また，金表面と試料の界面には，試料の屈折率に 対応した波数を持つプラズモン波が発生している。このエ バネッセント波とプラズモン波の波数が一致すると，その

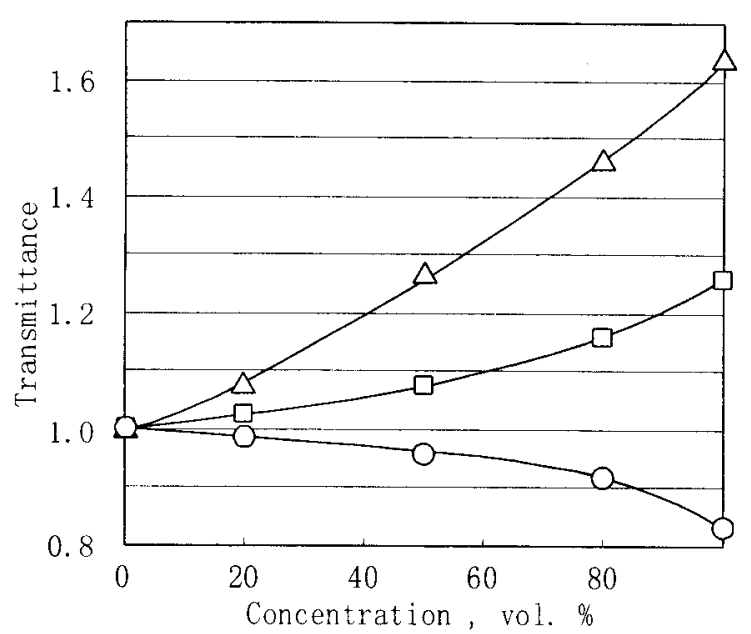

Fig. 2 Relationship between transmittance and the concentration of ethyl propionate, ethyl acetate, and ethyl formate in ethanol

$\triangle$ : ethyl propionate; $\square$ : ethyl acetate; $\bigcirc$ : ethyl formate

波数に対応した入射角の光のみが吸収される。このため， 屈折率に応答して光ファイバーを透過するレーザー光の透 過率が変化する.

\section{$2 \cdot 3$ 実験方法}

検知部への試料の導入はマイクロチューブポンプを用 い,ファイバーを透過してきた光の強度の変化を光マルチ メーターを用いて観測した。試料の測定温度は $25 \pm 11^{\circ} \mathrm{C}$ とし，測定試料は，すべてアルコール溶液として 0 〜 100 vol\%に濃度を調製して測定した。

\section{3 結果と考察}

\section{$3 \cdot 1$ カルボン酸エチルエステル}

エステル類は動植物の油脂やろう成分として自然界に存 在している。なかでも酢酸エチルなどの低級脂肪酸エステ ルは食用としての香料，有機合成材料，医薬品として多用 されている，そこで，はじめに低級脂肪酸エステルの本装 置による測定を試みた。すなわちギ酸エチル，酢酸エチル， プロピオン酸エチルを用い，その濃度-透過率曲線を測定 した。これらの結果を Fig. 2 に示す。ギ酸エチルでは, 透過率がやや減少傾向の濃度一透過率の関係を得たが，酢 酸エチル，プロピオン酸エチルでは濃度とともに透過晾が 増加する曲線を示した．Fig. 3 に金修飾光ファイバーセン サーシステムによるエチレングリコールの測定結果を示 す ${ }^{20)}$. 濃度 $40 \mathrm{vol} \%$ 以下の領域では減少傾向を示している 濃度一透過率関倸が，濃度 $40 \mathrm{vol} \%$ 以上，すなわち試料の 屈折率が 1.37 以上の濃度領域では增加傾向を示している. これは, 光ファイバー内で全反射をしているレーザー光の 


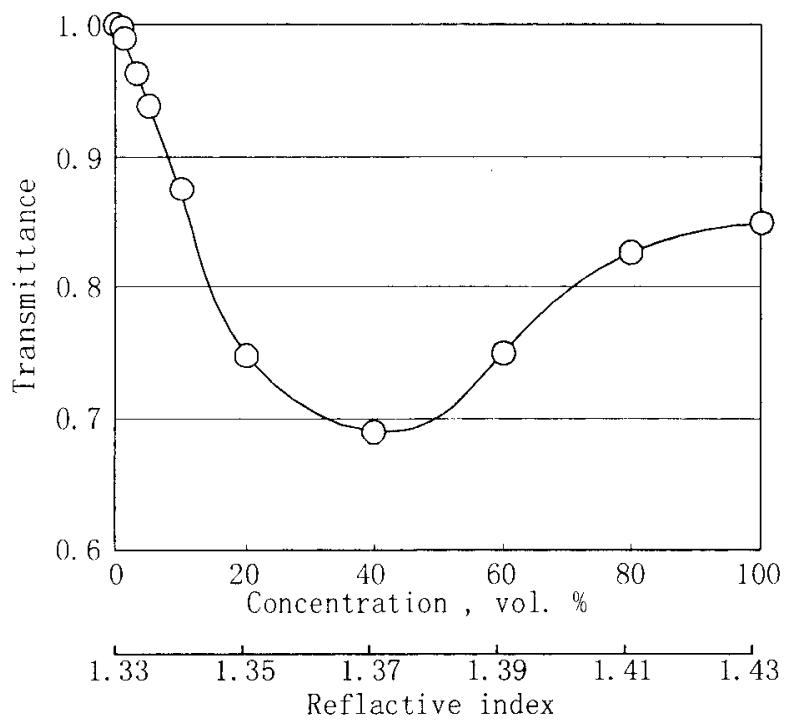

Fig. 3 Relationship between transmittance and the concentration of ethylene glycol in ethanol

The relevant refractive index values are also shown

角度範囲と、ファイバーに接触している試料と共鳴して吸 収を起こす角度を持つ物質の屈折率に関係している ${ }^{20)}$ 。す なわち本装置では, 物質の屈折率が拈よそ 1.37 が透過率 の增減の境界值である. ギ酸エチル, 酢酸エチル, プロピ オン酸エチルの屈折率 $\left(N_{0}{ }^{20}\right)$ はそれぞれ $1.3597,1.3719$, 1.3844 である ${ }^{11}$. 屈折率が 1.37 よりも小さなギ酸エチル のみが濃度一透過率関係が減少の傾向を示し, 屈折率が 1.37 以上の酰酸エチル，プロピオン酸エチルでは浱度一透 過率関係が増加の傾向を示している。これは, Fig. 3にお いて, 屈折率が 1.37 以下である $0 \sim 40 \mathrm{vol} \%$ の濃度領域 では濃度一透過率曲線が減少傾向を示すのに対し，40〜 $100 \mathrm{vol} \%$ の領域では増加傾向を示すことと同様の現象で ある。

\section{$3 \cdot 2$ ジカルボン酸ジエチルエステル}

ジカルボン酸ジエステルは, 合成潤滑剤, 可塑剂, 医薬 品など，非常に幅広い用途で用いられる物質である。また， DOS, DOA はジカルボン酸ジエステル系の高性能の合成 潤滑棛である。そこで, DOS, DOA と類似の構造を持つ セバシン酸ジエチル，アジピン酸ジエチル，及びマロン酸 ジエチルの金修飾光ファイバーセンサーシステムによる測 定を試みた。

これら化合物の構造式を Fig. 4(a)にまたさタノール 溶媒系からの濃度一透過率関係の測定結果を Fig. 5 に示 す。ジカルボン酸ジエチルエステルは, 濃度一透過率関係 がすべて増加傾向を示した。これは，マロン酸ジエチル， アジピン酸ジエチルの屈折率 $\left(N_{\mathrm{D}}{ }^{20}\right)$ がそれぞれ 1.4143, $1.42807^{211}$ であり, 試料の屈折率が 1.37 よりも大きいため

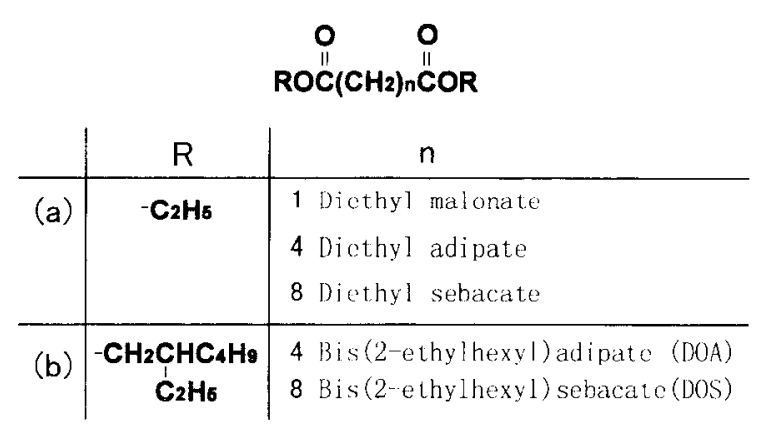

Fig. 4 Structural formula of dialkyl dicarboxylates

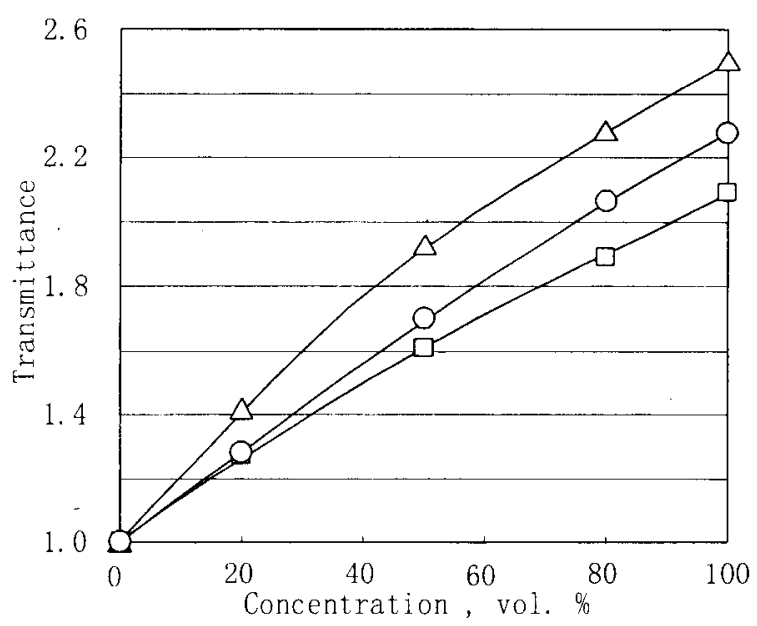

Fig. 5 Relationship between transmittance and the concentrations of diethyl sebacate, diethyl adipate, and diethyl malonate in ethanol

$\triangle$ : diethyl sebacate; $\square$ : diethyl adipate; $\bigcirc$ : diethyl malonate

である。また，セバシン酸ジエチルも，構造が類似のセバ シン酸ジオクチルの屈折率 $\left(\mathrm{N}_{\mathrm{I}}{ }^{29}\right)$ が 1.447 であることか ら，1.37 以上であることが予想される．透過率の変化は, セバシン酸ジエチルが最も大きく, アジピン酸ジエチルが 最も小さいが, 透過率の変化は Fig. 2 のカルボン酸エチ ルのものよりも大きく, 濃度変化に対してょり敏感に検出 可能であることが分かる.

\section{$3 \cdot 3$ DOS 及び DOA}

高性能潤滑剤の DOS 及び DOA の構造式は Fig. 4(b) に示すと扔りである，DOS，DOAなどのジエステル系潤 滑油は, 粘度が類似している石油に比べて粘度指数及び引 火点が高く，流動性が低い。また，潤滑性が良いなどの優 れた性質を持っており，低温潤滑剤や航空機潤滑剂等の過 酷な条件で用いられている。このため，性能の劣化に基づ く潤滑剤の濃度変化の測定が望まれる。

Fig. 6 にDOS 及びDOA に対する濃度一透過率関倸を示 


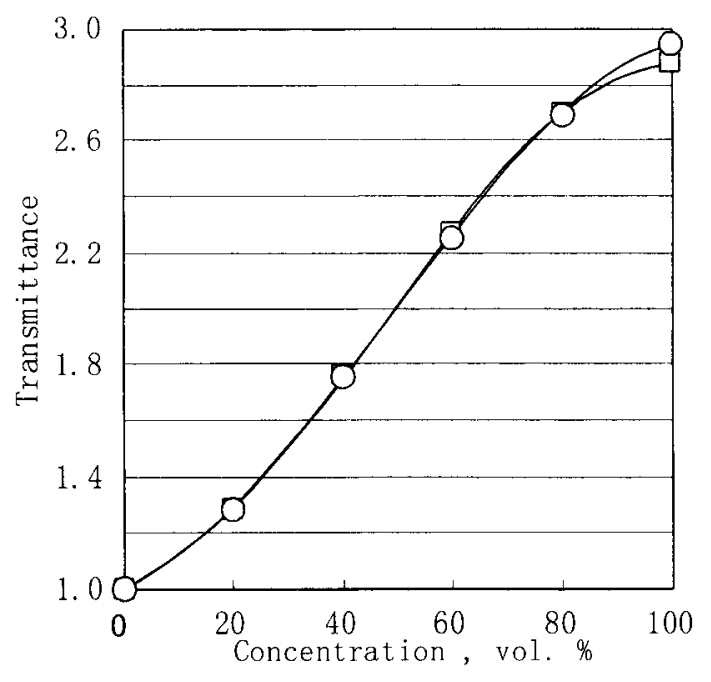

Fig. 6 Relationship between transmittance and the concentrations of DOS and DOA in ethanol

$\square$ : DOS; $O$ : DOA

す、溶媒にはエ夕ノールを用いて測定を行ったが，両者の 結果にはほとんど差は見られなかった，濃度変化に対する 透過率変化はほぼ全濃度領域にわたって比較的大きく高感 度であるため, 潤滑剤の分解などによる少化の検知及び測 定には十分応用可能であることが分かる。

\section{$3 \cdot 4$ 2-エチルヘキシルアルコール溶媒系からの DOS $の$} 応答

$3 \cdot 3$ から明らかなように, 金修飾光ファイバーセンサー システムを用いることにより，エステル系合成潤滑剂であ るDOS及びDOAの测定が可能であることが分かった。 DOS及びDOA は，アルミナ上において表面での触媒作 用によって酸とアルコールに加水分解されることが知られ ている ${ }^{22)}$. 加水分解ではセバシン酸やアジピン酸が生成す るが，これらは分解生成物の 2-エチルヘキシルアルコー ルにほとんど溶けず，またDOS/2-エチルヘキシルアルコ ール混合溶液にも溶解しない，そこで，DOS 及び 2-エチ ルヘキシルアルコールを用いて, DOSが表面で加水分解 された状態を想定して測定を試みた。Fig. 7 にDOS，2-工 チルヘキシルアルコール混合溶液の測定結果を示す。横軸 にはDOSの2-エチルヘキシルアルコールに刘するモル分 率，縦軸に透過率を示している. Fig. 7では, DOS/エ夕 ノール溶液（Fig. 6）のような大きな透過率の変化割合を 得ることはできなかったが，明らかにDOS 含量の減少に 伴って透過率が増加していることが分かる。これより， DOS 含量の減少量を金修飾光ファイバーセンサーを用い てリアルタイムで測定が可能であることが分かった。

本報では，金を蒸着したアンクラッドファイバーセンサ

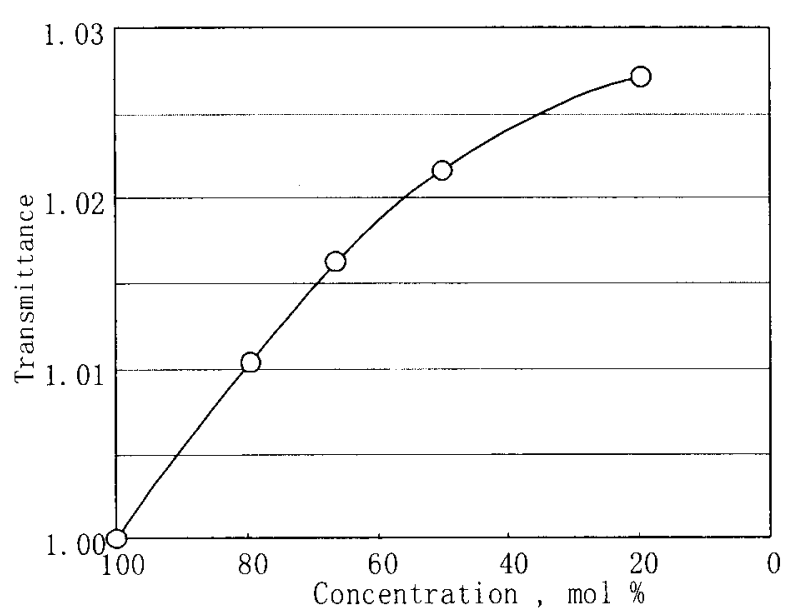

Fig. 7 Relationship between transmittance and the concentration of DOS in 2-ethylhexyl alcohol

ーシステムを用いて潤滑剤の劣化による濃度変化の測定に 対する基礎実験を行った。

金修飾アンクラッドファイバーセンサーを用いたセンサ 一により，カルボン酸エステルの測定が可能であることが 分かった, 更に, 本装置では, 濃度一透過率関係が屈折率 1.37 以下の領域では減少傾向，1.37 以上の領域では増加 傾向を示すことが分かったまた，本装置によるカルボン 酸エステルのほとんどは, 濃度に対する透過率の変化が大 きく，濃度変化の測定が容易に行えることが分かり，本装 置が潤滑剂の濃度変化に基ついた測定センサーとして十分 に応用できることを明らかにした。

\section{文献}

1) 化学大辞典編集委員会編: “化学大辞典”, 4, p. 83 (1978), (共立出版).

2) R. G. Larsen, A. Bondi: Industrial and Engineering Chemistry, 42, 2421 (1950).

3) R. R. Mod, F. C. Magne, G. Sumrell: J. Am. Oil Chem. Soc, , 54, 589 (1977).

4) B. R. Hohn, K. Michaelis, C. Eberspacher, L. Schlenk: Tribotest, 5, 383 (1999).

5) H. Heshmat, C. A. Heshmat: Tribol. Trans., 42, 640 (1999).

6) G. Ngaile, H. Saiki: Lubr. Eng., 55, 22 (1999).

7) M. D. DeGrandpre, L. W. Burgess: Anal. Chem., 60, 2582 (1988).

8) A. Safaai-Jazi, J. V. Peterson: Optics \& Laser Technology, 26, 399 (1994).

9) W. M. Henry: Sens. Actuators B, 22, 101 (1994).

10) C. D. Singh, B. D. Gupta: Appl. Opt., 34, 1019 (1995).

11) Y. Kurauchi, T. Yanai, N. Egashira, K. Ohga: Anal. Sci., 10, 213 (1994).

12) Y. Kurauchi, T. Ogata, N. Egashira, K. Ohga: Anal. Sci., 12, 55 (1996).

13) J. A. de Haseth, J. E. Andrews, J. V. Mcclusky, R. D. Priester Jr., M. A. Harthcock, B. L. Davis: Appl. 
Specrosc., 47, 173 (1993).

14) J. S. Sanghera, F. H. Kung, P. C. Pureza, V. Q. Nguyen, R. E. Miklos, I. D. Aggarwal: Appl. Opt., 33, 6315 (1994).

15) Z. Ge, C. W. Brown, M. Brown: J. Appl. Polym. Sci, 56, 667 (1995).

16) A. Fuchs, N. Sung: ANTEC '95, p. 2437 (1995).

17) L. C. Shriver-Lake, K. A. Breslin, P. T. Charles, D. W. Conrad, J. P. Golden, F. S. Ligler: Anal. Chem., 67, 2431 (1995).
18) Y. Kurauchi, K. Ohga: Anal. Sci., 6, 919 (1990).

19) Y. Kurauchi, R. Hayashi, N. Egashira, K. Ohga: Anal. Sci., 8, 837 (1992).

20) 満塩 勝, 鎌田薩男: 分析化学 (Bunseki kagaku), 48, 757 (1999).

21）有機合成化学協会編：“溶剂ポケットブック”, (1967), (才ーム社).

22) S. Kamata, A. Hida, M. Higo, H. Inadome: J. Phys. Chem., 98, 1648 (1994).

\section{要 旨}

光ファイバーのコアを被覆しているクラッドを除去した後に，露出させたコア表面上に金を蒸着し，これ を用いるセンサーシステムを構築した。このセンサーシステムを用い, 数種類のカルボン酸エチルエステル 及びジカルボン酸ジエチルエステルの濃度を, ファイバーを透過する光の強度の変化より測定した。 また, ジカルボン酸ジエステル系潤滑剤であるセバシン酸ビス 2-エチルヘキシル（DOS）及びアジピン酸ビス2 エチルヘキシル（DOA）についても測定を行い，潤滑剤の濃度センサーとしての応用を検討した，カルボ ン酸エチル及びジカルボン酸ジエチルエステルの測定ではほぼ全濃度領域において，DOS 及びDOAにつ いては 20〜80\%の濃度領域においてほぼ直線に近い濃度一透過率関係が得られ，容易に濃度の測定が可能 であることが分かった。これより，本装置による潤滑剤の濃度变化の测定を可能にすることができた。 